\title{
Ethinylestradiol differentially interferes with IGF-I in liver and extrahepatic sites during development of male and female bony fish
}

\author{
Natallia Shved, Giorgi Berishvili, Helena D'Cotta ${ }^{1}$, Jean-François Baroiller ${ }^{1}$, Helmut Segner ${ }^{2}$, \\ Elisabeth Eppler and Manfred Reinecke \\ Division of Neuroendocrinology, Institute of Anatomy, University of Zürich, Winterthurerstr. 190, CH-8057 Zürich, Switzerland \\ ${ }^{1}$ CIRAD-EMVT UPR20, Campus International de Baillarguet, F-34398 Montpellier, France \\ ${ }^{2}$ Centre for Fish and Wildlife Health, University of Bern, Länggasse 122, CH-3012 Bern, Switzerland \\ (Correspondence should be addressed to M Reinecke; Email: reinecke@anatom.uzh.ch)
}

\begin{abstract}
Growth and sexual development are closely interlinked in fish; however, no reports exist on potential effects of estrogen on the GH/IGF-I-axis in developing fish. We investigate whether estrogen exposure during early development affects growth and the IGF-I system, both at the systemic and tissue level. Tilapia were fed from 10 to 40 days post fertilization (DPF) with $17 \alpha$-ethinylestradiol $\left(\mathrm{EE}_{2}\right)$. At 50, 75, 90, and 165 DPF, length, weight, sex ratio, serum IGF-I (RIA), pituitary GH mRNA and IGF-I, and estrogen receptor $\alpha$ $(\mathrm{ER} \alpha)$ mRNA in liver, gonads, brain, and gills (real-time PCR) were determined and the results correlated to those of in situ hybridization for IGF-I. Developmental exposure to $E_{2}$ had persistent effects on sex ratio and growth. Serum IGF-I, hepatic IGF-I mRNA, and the number of IGF-I mRNA-containing hepatocytes were significantly decreased
\end{abstract}

at $75 \mathrm{DPF}$, while liver $\mathrm{ER} \alpha \mathrm{mRNA}$ was significantly induced. At 75 DPF, a transient decline of IGF-I mRNA and a largely reduced number of IGF-I mRNA-containing neurons were observed in the female brain. In both sexes, pituitary $\mathrm{GH}$ mRNA was significantly suppressed. A transient downregulation of IGF-I mRNA occurred in ovaries (75 DPF) and testes (90 DPF). In agreement, in situ hybridization revealed less IGF-I mRNA signals in granulosa and germ cells. Our results show for the first time that developmental estrogen treatment impairs GH/IGF-I expression in fish, and that the effects persist. These long-lasting effects both seem to be exerted indirectly via inhibition of pituitary $\mathrm{GH}$ and directly by suppression of local IGF-I in organ-specific cells.

Journal of Endocrinology (2007) 195, 513-523

\section{Introduction}

Insulin-like growth factor I (IGF-I) plays a central role in the complex system that regulates growth, differentiation, and reproduction. It selectively promotes mitogenesis and differentiation and inhibits apoptosis (Jones \& Clemmons 1995, Reinecke \& Collet 1998). IGF-I is mainly produced in liver the principal source of circulating (endocrine) IGF-I - under the influence of growth hormone $(\mathrm{GH})$. IGF-I released from the liver into the circulation acts on a variety of target cells. In addition, IGF-I is also expressed in extrahepatic sites and most likely stimulates organ-specific functions by paracrine/autocrine mechanisms. There is increasing evidence that $\mathrm{GH}$ stimulates the expression of IGF-I also in extrahepatic sites (Vong et al. 2003, Biga et al. 2004).

Among the non-mammalian vertebrate classes, bony fish are the most studied with respect to IGF-I (Duan 1998, Plisetskaya 1998, Wood et al. 2005, Reinecke 2006) mainly due to their unique development from larval to adult life and to their high importance in aquaculture. Thus, there is a rising interest in the significance of IGF-I in fish development, growth, and reproduction. In this respect, some evidence has been presented (Riley et al. 2004, Carnevali et al. 2005, McCormick et al. 2005) that estrogens may acutely influence synthesis and/or release of IGF-I from adult fish liver. Very recently, the influence of exposure to estrogen $\left(\mathrm{E}_{2}\right)$ on several genes, including IGF-I, has been investigated in adults of the fathead minnow (Filby et al. 2006). In contrast, possible effects of estrogens on the IGF-I system in developing fish have not been studied to date, although it is well documented that prolonged exposure of developing fish to exogenous estrogens is associated with impaired growth (Jobling et al. 2002, Rasmussen et al. 2002, Fenske et al. 2005). This suggests an influence of estrogen on the IGF-I system during development. In contrast to the activational effects of estrogens on the IGF system as reported for adult fish, developmental estrogen exposure may induce organizational alterations of the IGF-I system what could lead to persistent changes in growth and reproduction.

The present study aims to investigate the potential influence of $17 \alpha$-ethinylestradiol $\left(\mathrm{EE}_{2}\right)$ on IGF-I when applied to developing fish. A population of tilapia 
(Oreochromis niloticus) was fed with $\mathrm{EE}_{2}$ during the period of gonad sexual differentiation (10-40 days post fertilization, DPF) at the optimal dosage to induce functional feminization. We assessed whether $\mathrm{EE}_{2}$ treatment during this development stage exerts lasting effects on gonad differentiation, growth, and crucial parameters of the GH/IGF-I system. In addition, in order to assess potential lasting effects of developmental $\mathrm{EE}_{2}$ treatment on the estrogen system and the possible association with changes in the GH/IGF-I system, we measured estrogen receptor $\alpha(\mathrm{ER} \alpha)$ expression. The following parameters were determined after termination of estrogen treatment at 10, 35, 50, and 125 days posttreatment $(50,75,90$, and $165 \mathrm{DPF})$ : sex ratio, body length (BL) and body weight (BW), serum IGF-I levels, and mRNA expression levels of IGF-I, GH, and ER $\alpha$. Furthermore, we studied $\mathrm{EE}_{2}$-related alterations in IGF-I mRNA cellular localization in the potential target organs by in situ hybridization. The organs studied included those of the central GH/IGF-I axis, i.e., pituitary and liver. Although fish liver is the major source of circulating IGFI, IGF-I also occurs in extrahepatic sites (Reinecke et al. 1997) where it is particularly expressed during development (Duguay et al. 1996, Perrot et al. 1999, Radaelli et al. 2003, Berishvili et al. 2006a). Thus, the alterations in IGF-I mRNA expression were also determined in organs showing high IGF-I expression during ontogeny, i.e., gills and brain. We also examined the influence of $\mathrm{EE}_{2}$ exposure on IGF-I expression in the gonads. Gonads of developing fish express IGF-I mRNA (Berishvili et al. 2006b), although the functional role of IGF-I expression in the gonad, and its response to estrogen exposure are unknown yet. The examination of the IGF-I response to $\mathrm{EE}_{2}$ treatment in the various target organs and cells of male and female fish was accompanied by measuring expression of ER $\alpha$ mRNA in liver, pituitary, brain, gill filaments, and gonads, in order to evaluate whether the potential changes of the GH/IGF-I system are associated with an activation of the ER-signaling pathway.

\section{Materials and Methods}

\section{Fish culture and hormone treatment}

Balanced populations of tilapia (O. niloticus) were fed in September during a period, i.e., 10-40 DPF, covering the sensitive period with $\mathrm{EE}_{2}$ at the optimal dosage $(125 \mu \mathrm{g}$ $\mathrm{EE}_{2} / \mathrm{g}$ food) to induce functional feminization in most individuals. Principles of animal care and specific national laws were followed. Hormonally treated salmonid food was prepared by the ethanol evaporation method (0.61 of $95 \%$ ethanol $/ \mathrm{kg}$ food). $\mathrm{EE}_{2}$ (Sigma) was dissolved in 95\% ethanol and the solution was sprayed over the food. Control food was prepared in the same way without $\mathrm{EE}_{2}$. Three batches of 500 fry each were used for the treatment.
Fish sampling and tissue preparation

All experiments were performed three times. At the age of 50, 75, 90, and 165 DPF, fish were anesthetized with 2-phenoxy ethanol (Sigma) added to water and measured in weight and length. Blood samples were obtained from control (male: 75 DPF $n=7,90$ DPF $n=6,165$ DPF $n=9$; female: 75 DPF $n=7,90 \mathrm{DPF} n=7,165 \mathrm{DPF} n=12$ ) and $\mathrm{EE}_{2}$-treated (male: 75 DPF $n=7,90$ DPF $n=6,165$ DPF $n=7$; female: 75 DPF $n=8$, $90 \mathrm{DPF} n=8,165 \mathrm{DPF} n=9)$ tilapia. For real-time PCR, control (male: 50 DPF $n=12,75$ DPF $n=9$, 90 DPF $n=9,165 \mathrm{DPF} n=9$; female: $50 \mathrm{DPF} n=15,75 \mathrm{DPF} n=12$, 90 DPF $n=14,165$ DPF $n=12$ ) and $\mathrm{EE}_{2}$-treated (male: 50 DPF $n=12,75$ DPF $n=10,90 \operatorname{DPF} n=12,165$ DPF $n=11$; female: 50 DPF $n=12,75$ DPF $n=12,90$ DPF $n=14,165$ DPF $n=11$ ) tilapia were used. For in situ hybridization, tissue specimens of liver, brain, pituitary, gonads, and gill filaments sampled from three control and $\mathrm{EE}_{2}$-treated fish per sex and point of time were used.

\section{RIA for IGF-I}

Blood was collected from the caudal vein using a heparinized $1 \mathrm{ml}$ syringe, centrifuged for $15 \mathrm{~min}$ at $4{ }^{\circ} \mathrm{C}$ at $10000 \mathrm{~g}$ Serum was removed and stored at $-20^{\circ} \mathrm{C}$. Serum IGF-I levels were determined in undiluted samples by RIA after SepPak C18 chromatography (Waters Corp., Milford, MA, USA), as described earlier (Zapf et al. 2002). In brief, 0.15 ml PBS containing $0 \cdot 2 \%$ human serum albumin (HSA), $\mathrm{pH} 7 \cdot 4$, were added to $0 \cdot 1 \mathrm{ml}$ serum. All samples were acid treated and run over Sep-Pak C18 cartridges (Immunonuclear, Stillwater, MN, USA). After reconstitution with $1 \mathrm{ml} \mathrm{PBS} / 0 \cdot 2 \% \mathrm{HSA}$ tilapia, serum samples were assayed as already described (Eppler et al. 2007): three different dilutions $(1: 5,1: 10$, and $1: 20)$ in $0 \cdot 2 \mathrm{ml}$ samples or standards (fish IGF-I from GroPep, Adelaide, Australia) and 0.1 ml IGF-I antiserum (final dilution 1:20 000, GroPep) were preincubated for $24 \mathrm{~h}$ at $4{ }^{\circ} \mathrm{C}$. To the final incubation volume $(0 \cdot 4 \mathrm{ml}), 25000-35000$ c.p.m. ${ }^{125}$ I-IGF-I (Anawa, Wangen, Switzerland, specific activity 300-400 $\mu \mathrm{Ci}$ / $\mu \mathrm{l})$ were added. The reaction mixture was incubated for another $24 \mathrm{~h}$ followed by precipitation with goat anti-rabbit $\gamma$-globulin antiserum. After centrifugation, the pellet was counted in a $\gamma$-counter.

\section{Design of primers and probes for real-time PCR}

Based on the mRNA sequences of O. mossambicus IGF-I (Reinecke et al. 1997), O. niloticus GH (Ber \& Daniel 1992), and $\beta$-actin (Hwang et al. 2003), specific primers and probes for real-time PCR were created as already described (Caelers et al. 2004, 2005) for IGF-I (sense TCTGTGGAGAGCGAGGCTTT, antisense CACGTGACCGCCTTGCA, probe ATTTCAATAAACCAACAGGCTATGGCCCCA), GH (sense TCGACAAACACGAGACGCA, antisense CCCAGGACTCAACCAGTCCA, probe CGCAGCTCGGTCCTGAAGC$\mathrm{TG}$ ), and $\beta$-actin as a house-keeping gene (sense GC 
CCCACCTGAGCGTAAATA, antisense AAAGGTGGACAGGAGGCCA, probe TCCGTCTGGATCGGAGGCTTCATC). Using this method, new primers and probe (sense CAAGTGGTGGAGGAGGAAGATC, antisense CTCAGCACCCTGGAGCAG, probe CTGATCAGGTGCTCCTC) were designed for $\mathrm{ER} \alpha$ based on the O. niloticus $\mathrm{ER} \alpha$ sequence (Chang et al. 1999) with Primer Express software version 1.5 (PE Biosystems, Foster City, CA, USA).

\section{Real-time PCR quantitation of IGF-I, ER- $\alpha$, and GH expression}

Total RNA was extracted from specimens stored in $1.5 \mathrm{ml}$ RNAlater (Ambion, Austin, TX, USA) using TRIzol reagent (Invitrogen) and treated with $1 \mathrm{U}$ RQ1 RNAse-free DNAse (Catalys AG, Wallisellen, Switzerland). cDNA was synthesized from 800 ng total RNA using $1 \times$ TaqMan RT Buffer, $\mathrm{MgCl}_{2}$ $(5.5 \mathrm{mM}), 1.25 \mathrm{U} / \mu \mathrm{l}$ murine leukemia virus $(\mathrm{MuLV})$ reverse transcriptase, $2.5 \mu \mathrm{M}$ random hexamers primers, $0.4 \mathrm{U} / \mu \mathrm{l}$ ribonuclease inhibitor, and $500 \mu \mathrm{M}$ each dNTP (Applied Biosystems, Rotkreuz, Switzerland) for $10 \mathrm{~min}$ at $25^{\circ} \mathrm{C}$, $30 \mathrm{~min}$ at $48^{\circ} \mathrm{C}$, and $5 \mathrm{~min}$ at $95^{\circ} \mathrm{C}$. From $10 \mathrm{ng} / \mu \mathrm{l}$ total RNA, $2 \mu \mathrm{l}$ cDNA were obtained and were subjected, in triplicates, to real-time PCR using Absolute QPCR low ROX Mix (ABgene, Hamburg, Germany) including Thermo-Start DNA Polymerase, $300 \mathrm{nM}$ of each primer, $150 \mathrm{nM}$ of the fluorogenic probe. Amplification was performed with $10 \mu \mathrm{l}$ in a MicroAmp Fast Optical 96-well reaction plate using the ABI 7500 Fast Real-Time PCR System (Applied Biosystems) with the conditions: $15 \mathrm{~min}$ at $95^{\circ} \mathrm{C}$, followed by 40 cycles for $15 \mathrm{~s}$ at $95^{\circ} \mathrm{C}$ and for $1 \mathrm{~min}$ at $60^{\circ} \mathrm{C}$.

\section{Relative quantification of treatment effects using the $\Delta \Delta \mathrm{C}_{T}$ method}

The comparative threshold cycle $\left(\Delta \Delta C_{\mathrm{T}}\right)$ method (Livak \& Schmittgen 2001) was used to calculate relative gene expression ratios between $\mathrm{EE}_{2}$-treated and control groups. Data were normalized to $\beta$-actin as the reference gene. Efficiency tests for $\beta$-actin and IGF-I assays (Caelers et al. 2004) and ER $\alpha$ assay (data not shown) permitted the accurate use of the $\Delta \Delta C_{\mathrm{T}}$ method. Relative changes induced by $\mathrm{EE}_{2}$ feeding were calculated by the formula $2^{-\Delta \Delta C}$, with $\Delta \Delta C_{\mathrm{T}}=\Delta C_{\mathrm{T}}$ (treated group) $-\Delta C_{\mathrm{T}}$ (untreated control), and $\Delta C_{\mathrm{T}}=C_{\mathrm{T}}$ (target gene) $-C_{\mathrm{T}}$ (reference gene). All data are expressed as $n$-fold changes of gene expression in the experimental group relative to the control group, displayed in the graphs as 2 log scale, a common way of presenting qPCR data (e.g., Dzidic et al. 2006). Statistical significance was calculated using Mann-Whitney rank sum test, with an exact $P$ value. Statistical analyses were performed with GraphPad Prism 4 (GraphPad, San Diego, CA, USA).

\section{Tissue preparation of paraplast sections and in situ hybridization}

Samples were fixed by immersion in Bouin's solution for $4 \mathrm{~h}$ at room temperature, dehydrated in ascending series of ethanol and routinely embedded in paraplast $\left(58^{\circ} \mathrm{C}\right)$. Sections were cut at $4 \mu \mathrm{m}$ and processed for in situ hybridization using the sense $\left(5^{\prime}\right.$-GTCTGTGGAGAGCGAGGCTTT- $\left.3^{\prime}\right)$ and antisense (5'-AACCTTGGGTGCTCTTGGCATG-3') probes corresponding to the tilapia IGF-I B and E domains, as described (Schmid et al. 1999, Berishvili et al. 2006a,b). After dewaxing and rehydration, the sections were postfixed with $4 \%$ paraformaldehyde and $0 \cdot 1 \%$ glutaraldehyde in PBS. The following steps were carried out with diethylpyrocarbonate (DEPC)-treated solutions in a humidified chamber. The sections were digested with $0.02 \%$ proteinase $\mathrm{K}$ in $20 \mathrm{mM}$ Tris- $\mathrm{HCl}\left(\mathrm{pH} \mathrm{7 \cdot 4),2 \textrm {mM } \mathrm { CaCl }}\right.$ for $10 \mathrm{~min}$ at $37^{\circ} \mathrm{C}$ and treated with $1.5 \%$ triethanolamine and $0 \cdot 25 \%$ acetic anhydride for $10 \mathrm{~min}$ at room temperature. Slides were incubated with $100 \mu \mathrm{l}$ prehybridization solution per section for $3 \mathrm{~h}$ at $54{ }^{\circ} \mathrm{C}$ and hybridized overnight at $54{ }^{\circ} \mathrm{C}$ with $50 \mu \mathrm{l}$ hybridization buffer containing $200 \mathrm{ng}$ sense (negative control) or antisense probes previously denaturated for $5 \mathrm{~min}$ at $85^{\circ} \mathrm{C}$. Slides were washed for $15 \mathrm{~min}$ at room temperature in $2 \times \mathrm{SSC}$ and for $30 \mathrm{~min}$ at the specific hybridization temperature at descending concentrations of SSC $(2 \times, 1 \times, 0.5 \times$, and $0.2 \times)$. The sections were incubated with alkaline phosphatase-coupled anti-digoxigenin antibody diluted (1: 4000) in 1\% blocking reagent (Roche Diagnostics) in buffer P1 for $1 \mathrm{~h}$ at room temperature in the darkness. After washing in buffer P1, sections were treated with buffer P3, $5 \mathrm{mM}$ levamisole, and Nitroblue tetrazolium chloride (NBT)/5-bromo-4-chloro-3-indolyl phosphate p-toluidine salt (BCIP) stock solution (Roche Diagnostics). Color development was carried out overnight at room temperature and stopped by rinse of the slides in tap water for $15 \mathrm{~min}$.

\section{Results}

\section{Specificity of in situ hybridization}

Specificity of the probes as previously demonstrated for adult tilapia male and female gonads (Schmid et al. 1999, Berishvili et al. 2006b) and liver (Schmid et al. 1999) was reassured on adjacent sections of 50 DPF male brain with IGF-I antisense (Fig. 1A) and sense (Fig. 1B) probes and gills. In situ hybridization revealed positive signals with the antisense probe whereas no signals were present in the negative controls.

\section{Sex ratio}

After $\mathrm{EE}_{2}$ treatment, the sex ratio had shifted from $47 \cdot 2 \pm 8 \cdot 5 \%$ females in control to $86 \cdot 5 \pm 14 \cdot 1 \%$ females at $165 \mathrm{DPF}$

\section{Body length and weight}

$\mathrm{EE}_{2}$ treatment caused a progressive decrease in $\mathrm{BL}$ and $\mathrm{BW}$ in both sex (Fig. 2). Both parameters were significantly lowered from $90 \mathrm{DPF}$ onwards (90 DPF - BL: $-16 \cdot 9 \%$ in males, $-13 \cdot 4 \%$ in females; BW: $-47 \cdot 4 \%$ in males, $-32 \cdot 3 \%$ in females; 165 DPF - BL: $-19 \cdot 5 \%$ in males, $-15 \cdot 2 \%$ in females; BW: $-46 \cdot 2 \%$ in males, $-40 \cdot 1 \%$ in females). 

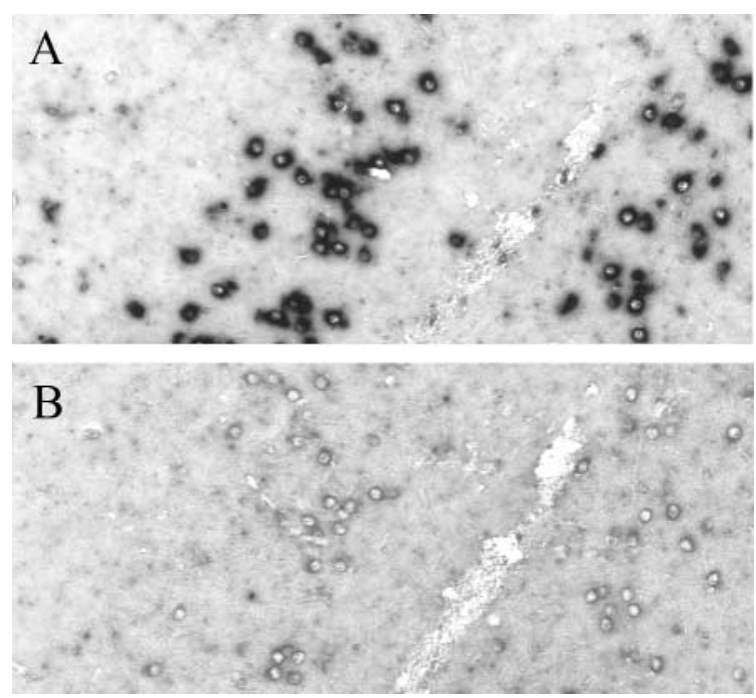

Figure 1 Specificity of the in situ hybridization technique shown on two adjacent sections of 50 DPF male tilapia brain hybridized with (A) an IGF-I antisense probe and (B) an IGF-I sense probe.

\section{Serum IGF-I level}

While at 50 DPF the fish were too small to allow blood drawing, blood could be taken at 75, 90, and 165 DPF. At 75 DPF, in males (Fig. 3G), the IGF-I serum level was significantly $(P=0 \cdot 002)$ decreased in the $\mathrm{EE}_{2}$-treated group $(5 \cdot 65 \pm 1.18 \mathrm{ng} / \mathrm{ml})$ when compared with the controls $(9.70 \pm 2.06 \mathrm{ng} / \mathrm{ml}$ ), while in females (Fig. $3 \mathrm{H})$ there was only a trend to reduce IGF-I serum level (control $11 \cdot 20 \pm 2 \cdot 18$ versus $\mathrm{EE}_{2}$-treated $\left.8 \cdot 54 \pm 2 \cdot 26, P=0 \cdot 08\right)$. At the later stages, there was no significant difference between the treated group and the controls (Fig. 3G and H).

\section{IGF-I and $E R \alpha m R N A$ levels in liver}

Hepatic IGF-I mRNA was significantly reduced by $\mathrm{EE}_{2}$ feeding with the effect becoming evident in females (Fig. 3C) later than in males (Fig. 3A). At 50 DPF, IGF-I mRNA in liver was lowered in males by $7 \cdot 1$-fold $(P=0 \cdot 05)$, at $75 \mathrm{DPF}$ in males by 3 -fold $(P=0 \cdot 01)$ and in females by $2 \cdot 7$-fold $(P=0 \cdot 002)$, at $90 \mathrm{DPF}$ in males by $1 \cdot 7$-fold $(P=0 \cdot 02)$ and in females by 5 -fold $(P=0 \cdot 0003)$ and almost recovered in both sex at 165 DPF (Fig. 3A and C). In situ hybridization revealed a markedly reduced number of hepatocytes containing IGF-I mRNA after $\mathrm{EE}_{2}$ treatment at 50 (Fig. $3 \mathrm{E}$ and F) and $75 \mathrm{DPF}$ in male liver and at 75 and 90 DPF in female liver. Hepatic ER $\alpha$ mRNA was significantly increased to $6 \cdot 1$-fold in males after $\mathrm{EE}_{2}$ feeding $(P=0 \cdot 01)$ and $2 \cdot 6$-fold $(P=0 \cdot 004)$ in females at $50 \mathrm{DPF}$ (Fig. $3 \mathrm{~B}$ and D). At $75 \mathrm{DPF}, \mathrm{ER} \alpha \mathrm{mRNA}$ was raised to $2 \cdot 2$-fold in males $(P=0 \cdot 02)$ and 37 -fold in females $(P=0 \cdot 002)$. In male liver, ER $\alpha$ was back at the
A $\mathrm{cm} \quad$ Body length male
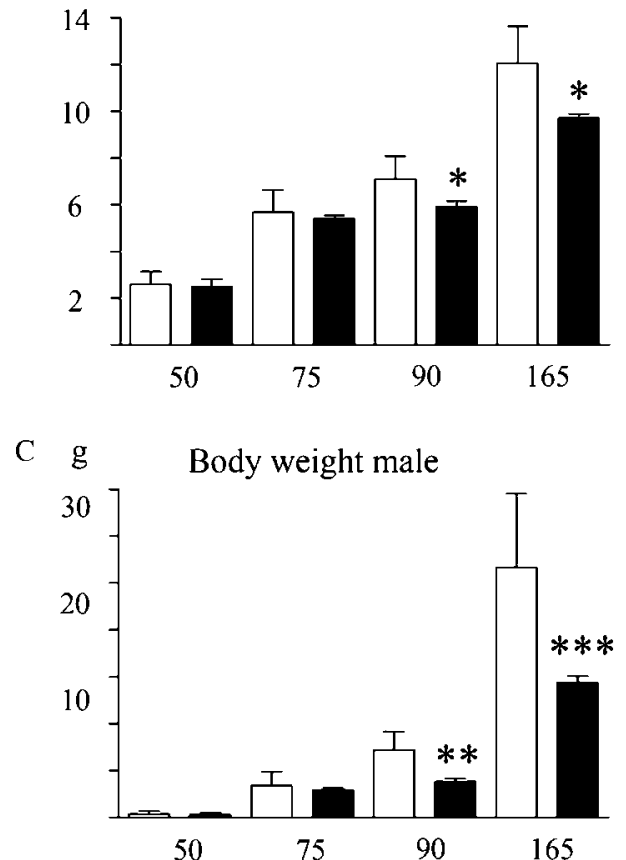

$\mathrm{B} \mathrm{cm}$

Body length female

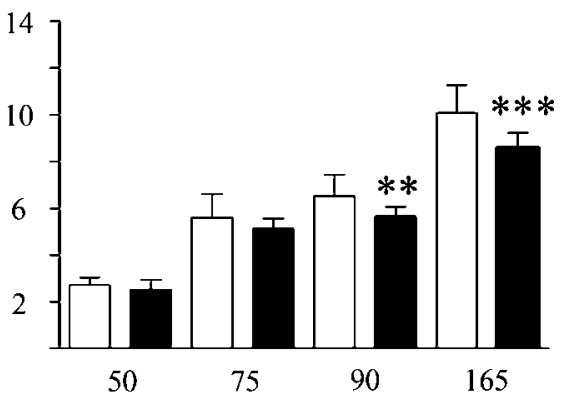

D $g$

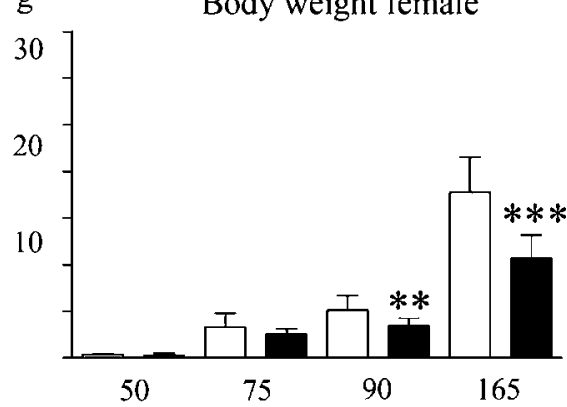

Figure 2 Influence of $\mathrm{EE}_{2}$ exposure on fish growth throughout the experimental period. Body length (in $\mathrm{cm}$ ) and weight (in $\mathrm{g}$ ) in ( $\mathrm{A}$ and $\mathrm{C}$ ) male and ( $\mathrm{B}$ and $\mathrm{D}$ ) female control (white columns) and $\mathrm{EE}_{2}$-treated (black columns) tilapia. $X$-axis is labeled as DPF. Columns denote mean values and bars denote s.D. Significance levels: ${ }^{*} P<0 \cdot 01,{ }^{* *} P<0 \cdot 005,{ }^{* * *} P<0 \cdot 0005$. 
A Liver male IGF-I

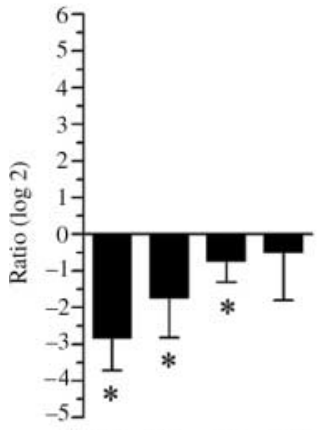

$\begin{array}{llll}50 & 75 & 90 & 165\end{array}$
B Liver male ER $\alpha$

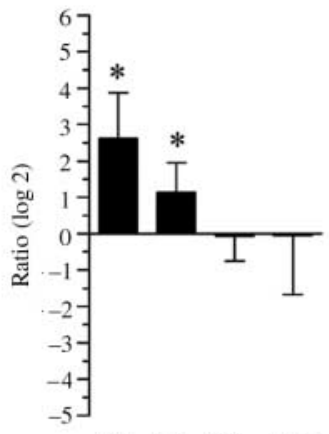

$\begin{array}{llll}50 & 75 & 90 & 165\end{array}$

Liver male IGF-I (50 DPF)

E Control

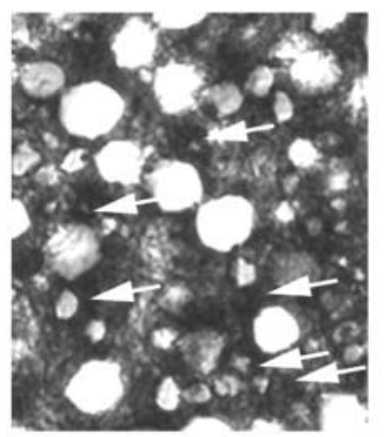

F $\quad E_{2}$-treated

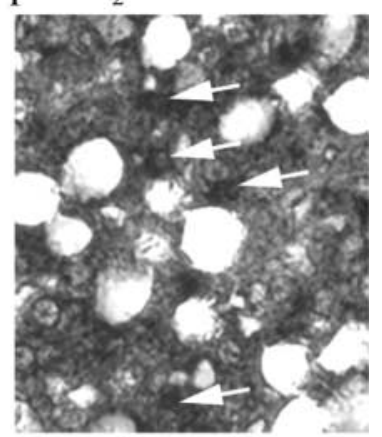

C Liver female IGF-I

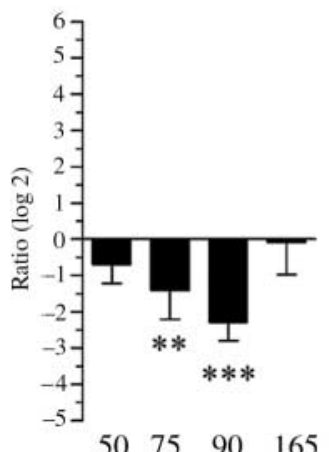

D Liver female ER $\alpha$

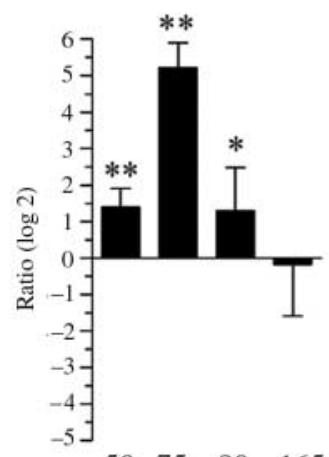

Serum IGF-I

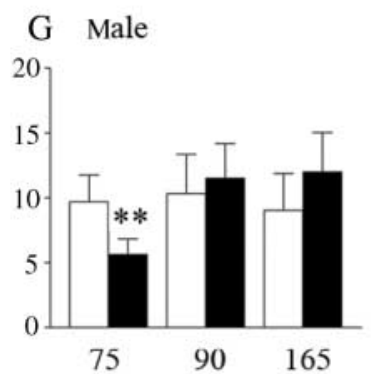

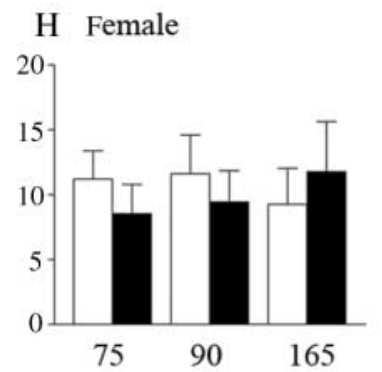

$\begin{array}{llll}50 & 75 & 90 & 165\end{array}$

Figure 3 Influence of $\mathrm{EE}_{2}$ exposure on IGF-I and $\mathrm{ER} \alpha$ gene expression in liver and on IGF-I peptide levels in serum. Relative changes $(\log 2)$ of $(A$ and $C)$ IGF-I and (B and D) ER $\alpha$ mRNA expression in $\mathrm{EE}_{2}$-treated tilapia when compared with age-matched control tilapia. Control (male: 50 DPF $n=12,75$ DPF $n=9,90$ DPF $n=9$, 165 DPF $n=9$; female: 50 DPF $n=15,75$ DPF $n=12,90$ DPF $n=14,165$ DPF $n=12$ ) and $\mathrm{EE}_{2}$-treated (male: $50 \mathrm{DPF} n=12,75$ DPF $n=10,90$ DPF $n=12,165$ DPF $n=11$, female: 50 DPF $n=12,75$ DPF $n=12,90$ DPF $n=14,165$ DPF $n=11$ ) tilapia were used. Normalization was performed with $\beta$-actin as housekeeping gene. In situ hybridization with IGF-I antisense probe of tilapia liver specimens in 50 DPF old (E) control and (F) $\mathrm{EE}_{2}$-treated male tilapia. White arrows point to IGF-I mRNA-expressing hepatocytes. IGF-I peptide concentrations in serum determined by a fish-specific RIA in control (white columns) and $\mathrm{EE}_{2}$-treated (black columns) $(\mathrm{G})$ male and $(\mathrm{H})$ female fish. Blood samples were obtained from control (male: 75

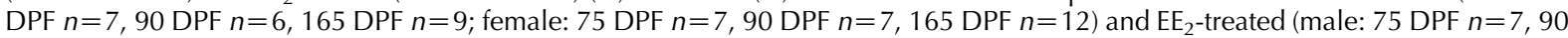
DPF $n=6$, 165 DPF $n=7$; female: 75 DPF $n=8,90$ DPF $n=8,165$ DPF $n=9$ ) tilapia. $X$-axis is labeled as DPF. Columns denote mean values and bars denote S.D. Significance level: ${ }^{*} P=0 \cdot 05, P=0 \cdot 02, P=0 \cdot 01 ;{ }^{* *} P=0 \cdot 002, P=0 \cdot 004 ;{ }^{* * *} P=0 \cdot 0003$.

normal level at 90 DPF. In female liver, ER $\alpha$ at 90 DPF was still raised to $2 \cdot 5$-fold $(P=0 \cdot 05)$ of the control mRNA and at about the normal level at 165 DPF.

\section{IGF-I and ER $\alpha m R N A$ levels in brain}

In the male brain, no significant change in the expression of IGF-I mRNA was detected throughout the experimental period (Fig. 4A). In the female brain, however, at $75 \mathrm{DPF}$ IGF-I mRNA was significantly $(P=0 \cdot 001)$ reduced $(3 \cdot 45-$ fold). At 90 and 165 DPF, IGF-I mRNA was about the normal level (Fig. 4C). At 75 DPF, in all regions of the female brain (Fig. 4F), the number of neurons showing IGF-I mRNA was largely reduced when compared with control (Fig. 4E). Brain ER $\alpha$ mRNA exhibited no significant changes at any experimental stage (Fig. 4B and D).

\section{IGF-I and ER $\alpha \mathrm{mRNA}$ levels in male and female gonads}

No alteration in the expression of IGF-I was detected at $50 \mathrm{DPF}$ (Fig. 5A and C). At 75 DPF, there was a significant $(P=0 \cdot 015)$ decrease $(-2 \cdot 2$-fold) in the IGF-I mRNA level in the female gonad and at $90 \mathrm{DPF}$, there was a significant $(P=0 \cdot 0013)$ reduction $(-2 \cdot 5$-fold) of IGF-I mRNA in the male gonad. At the later stages, IGF-I mRNA reached the normal level. In situ hybridization of male gonad at $90 \mathrm{DPF}$ revealed that the number of IGF-I mRNA containing spermatogonia was markedly lower in $\mathrm{EE}_{2}$-treated (Fig. 5F) fish than in control (Fig. 5E). Less IGF-I mRNA signals were observed in granulosa cells of the ovaries in $\mathrm{EE}_{2}$-treated fish at $75 \mathrm{DPF}$ (Fig. $5 \mathrm{H}$ ). Furthermore, IGF-I mRNA in small oocytes as present in controls (Fig. 5G) was largely reduced. In the male gonads, a significant increase in ER $\alpha$ mRNA was found at $50 \mathrm{DPF}$ 


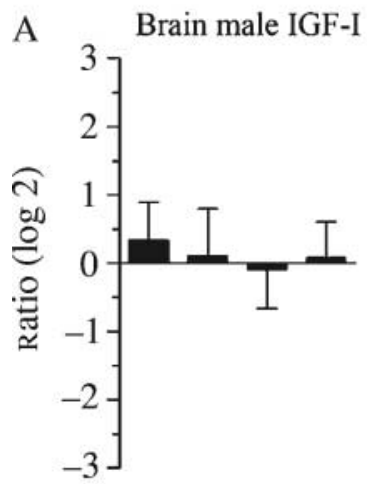

$\begin{array}{llll}50 & 75 & 90 & 165\end{array}$

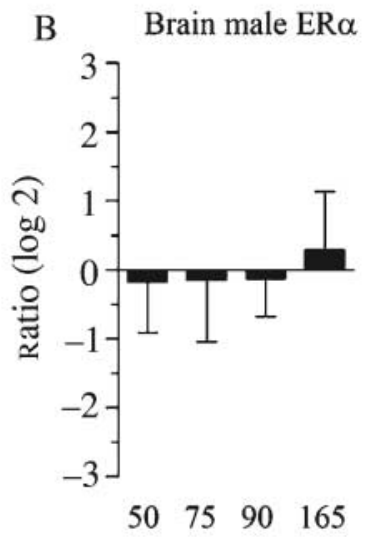

\section{Brain female IGF-I (75 DPF)}

E Control

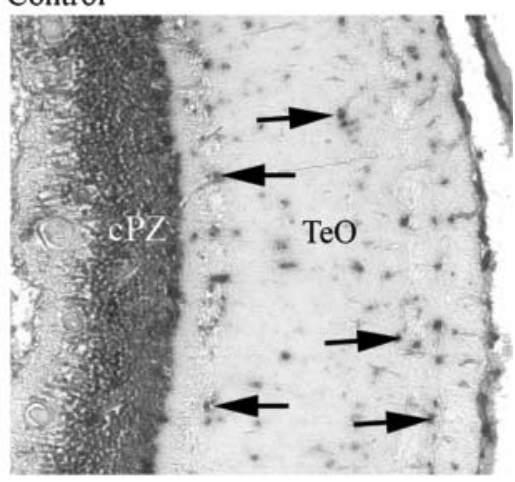

$\mathrm{EE}_{2}$-treated
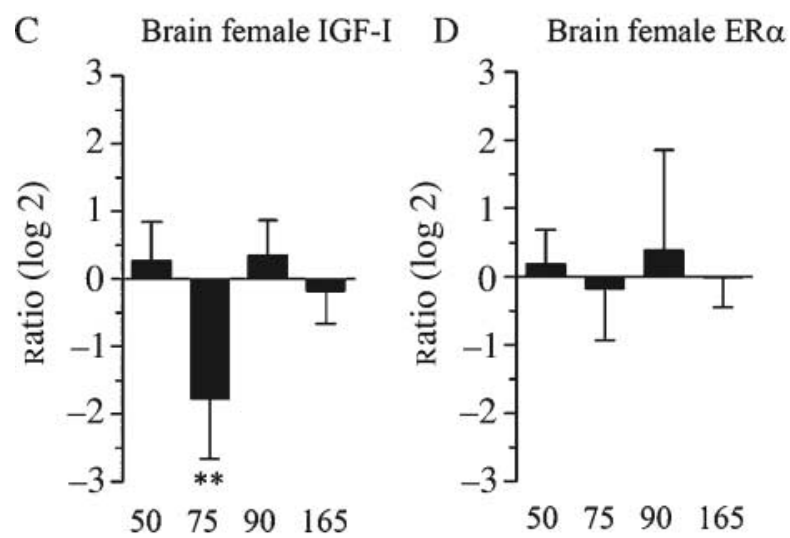

$\mathrm{F}$

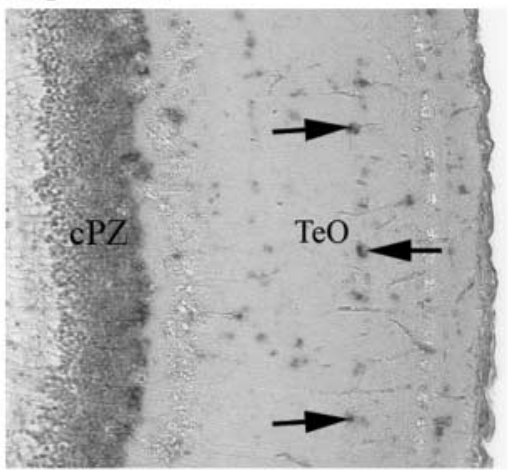

Figure 4 Influence of $\mathrm{EE}_{2}$ exposure on IGF-I and $\mathrm{ER} \alpha$ gene expression in brain. Relative changes $(\log 2)$ of $(\mathrm{A}$ and $\mathrm{C}) \mathrm{IGF}-\mathrm{I}$ and $(\mathrm{B}$ and $\mathrm{D})$ $\mathrm{ER} \alpha \mathrm{mRNA}$ expression in $\mathrm{EE}_{2}$-treated when compared with age-matched control tilapia. Control (male: $50 \mathrm{DPF} n=12,75 \mathrm{DPF} n=9,90$ DPF $n=9$, 165 DPF $n=9$; female: 50 DPF $n=15,75$ DPF $n=12,90$ DPF $n=14,165$ DPF $n=12$ ) and $\mathrm{EE}_{2}$-treated (male: 50 DPF $n=12$, 75 DPF $n=10,90$ DPF $n=12,165$ DPF $n=11$, female: 50 DPF $n=12,75$ DPF $n=12$, 90 DPF $n=14,165$ DPF $n=11$ ) tilapia were used. Normalization was performed with $\beta$-actin as house-keeping gene. In situ hybridization with IGF-I antisense probe of tilapia brain specimens in 75 DPF old (E) control and (F) $\mathrm{EE}_{2}$-treated female tilapia. In the cell body layer of the periventriclar zone (cPZ) and the tectum opticum (TeO), the number of IGF-I mRNA expressing neurons (black arrows) is largely reduced in the $\mathrm{EE}_{2}$-treated brain. $X$-axis is labeled as DPF. Columns denote mean values and bars denote s.D. Significance level: ${ }^{*} P=0 \cdot 001$.

(4·4-fold, $P=0 \cdot 015)$, 75 DPF $(4 \cdot 2$-fold, $P=0 \cdot 028)$, and 90 DPF $(2 \cdot 6$-fold, $P=0 \cdot 009$; Fig. $5 \mathrm{~B})$. In contrast, in the female gonad, a significant $(P=0 \cdot 015)$ increase in $\mathrm{ER} \alpha \mathrm{mRNA}$ was obtained only at 50 DPF by 1.78 -fold followed by a significant decrease $(-1.79$-fold, $P=0.006)$ at 75 DPF. At 90 DPF, there was only a tendency $(P=0 \cdot 11)$ to decrease ER $\alpha$ mRNA. At 165 $\mathrm{DPF}, \mathrm{ER} \alpha \mathrm{mRNA}$ was at the normal level.

\section{IGF-I and ER $\alpha \mathrm{mRNA}$ levels in gill filaments}

Significant changes in IGF-I mRNA expression were obtained only at $50 \mathrm{DPF}$ in males where it was decreased by $5 \cdot 9$-fold $(P=0 \cdot 02)$. No significant changes in IGF-I mRNA were detected in males later on or in females at any experimental stage (Fig. 6A and C). Using in situ hybridization, the number of IGF-I mRNA containing chloride cells in the gill filament epithelium was found to be reduced in $\mathrm{EE}_{2}$-treated males at 50 DPF (Fig. 6E and F). At 50 DPF, branchial ER $\alpha$ mRNA was significantly decreased in both sex, in males by 27 -fold $(P=0 \cdot 03)$ and in females by $3 \cdot 2$-fold $(P=0 \cdot 03)$. At the later stages, no significant changes were obtained (Fig. $6 \mathrm{~B}$ and $\mathrm{D}$ ).

\section{Pituitary GH and ER $\alpha$ mRNA levels}

Pituitaries could be dissected only at 75, 90, and 165 DPF.GH mRNA was significantly decreased after $\mathrm{EE}_{2}$ treatment in male pituitary at $165 \mathrm{DPF}(P=0.0571)$ by 2.33 -fold (Fig. 7A) and in female pituitary at $75 \mathrm{DPF}$ by $2 \cdot 27$-fold $(P=0 \cdot 0571)$ and at $90 \mathrm{DPF}$ to 3 -fold $(P=0 \cdot 0571 ;$ Fig. $7 \mathrm{C})$. ER $\alpha$ mRNA was significantly $(P=0.0061)$ raised to $3 \cdot 38$-fold at $165 \mathrm{DPF}$ in the male pituitary (Fig. 7B) and in the female pituitary to $2 \cdot 55$-fold at $75 \operatorname{DPF}(P=0.0159)$ and at $90 \mathrm{DPF}(P=0 \cdot 0012)$ to $2 \cdot 7$-fold (Fig. 7D). 


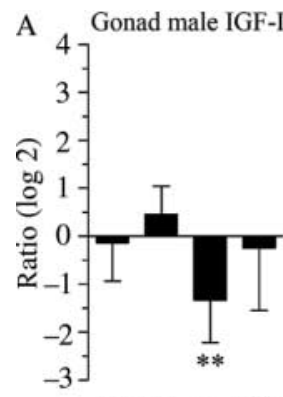

$50 \quad 75 \quad 90 \quad 165$

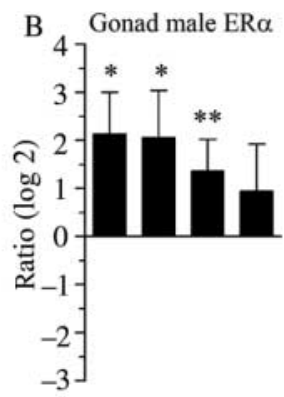

$50 \quad 75 \quad 90 \quad 165$

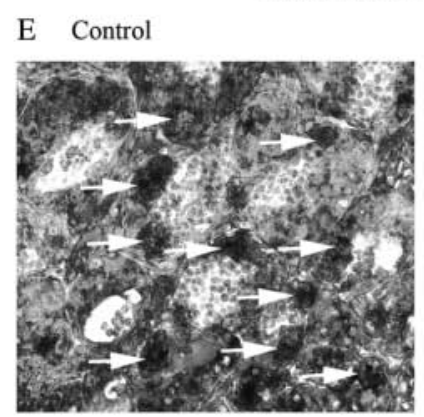

Gonad male IGF-I (90 DPF)

F $\mathrm{EE}_{2}$-treated

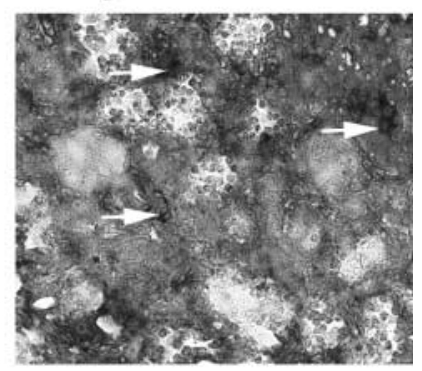

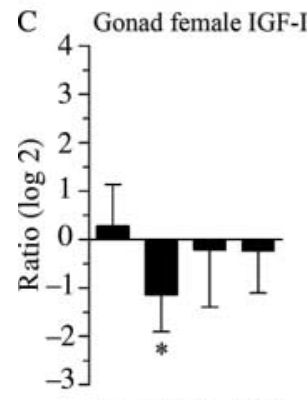

$\begin{array}{llll}50 & 75 & 90 & 165\end{array}$

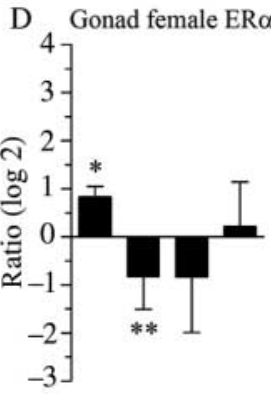

$50 \quad 75 \quad 90 \quad 165$
Gonad female IGF-I (75 DPF)

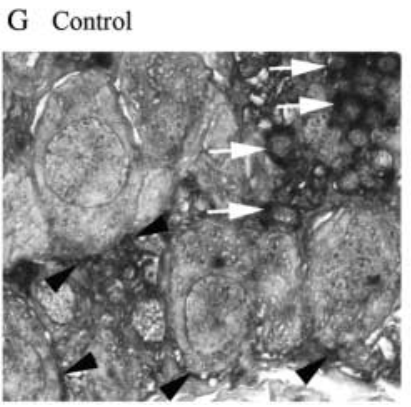

$\mathrm{H} \quad \mathrm{EE}_{2}$-treated

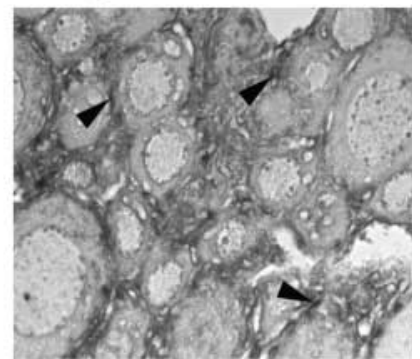

Figure 5 Influence of $\mathrm{EE}_{2}$ exposure on IGF-I gene expression in male and female gonad. Relative changes (log 2) of (A and C) IGF-I and $(B$ and $D) E R \alpha m R N A$ expression in $\mathrm{EE}_{2}$-treated tilapia when compared with age-matched control tilapia. Control (male: 50 DPF $n=12,75$ DPF $n=9,90$ DPF $n=9,165$ DPF $n=9$; female: 50 DPF $n=15,75$ DPF $n=12,90$ DPF $n=14,165$ DPF $n=12)$ and $\mathrm{EE}_{2}$-treated (male: $50 \mathrm{DPF} n=12,75$ DPF $n=10,90$ DPF $n=12,165$ DPF $n=11$, female: 50 DPF $n=12,75$ DPF $n=12,90$ DPF $n=14,165$ DPF $n=11$ ) tilapia were used. Normalization was performed with $\beta$-actin as house-keeping gene. (E-H) In situ hybridization with IGF-I antisense probe. (E and F) Male gonad at 90 DPF. Arrows point to IGF-I mRNA-expressing spermatogonia. (G and $\mathrm{H}$ ) Female gonad at 75 DPF. Fewer IGF-I mRNA signals are found in granulosa cells (black arrow heads) and in small oocytes (white arrows) of $(\mathrm{H}) \mathrm{EE}_{2}$-treated fish than in $(\mathrm{G})$ controls. $X$-axis is labeled as DPF. Columns denote mean values and bars denote s.D. Significance level: $* P=0 \cdot 028, P=0 \cdot 015, * * P=0 \cdot 006, P=0 \cdot 009, P=0 \cdot 0013$.

\section{Discussion}

Nothing is known about the potential interference of estrogen(s) and IGF-I during fish development. In our study, $\mathrm{EE}_{2}$ feeding from 10 to $40 \mathrm{DPF}$, a period that includes the sensitive period of gonad differentiation, led to a lasting decline in growth that was most pronounced at the end of the experiment (165 DPF), i.e. about 3 months after end of the treatment. Then, BW was reduced when compared with controls in males by about $46 \%$ and BL by $19 \cdot 5 \%$, and in females by about 40 and $15 \%$ respectively. Thus, $\mathrm{EE}_{2}$ feeding for about 1 month during the sensitive phase of sexual development resulted in severe and persistent growth impairment in both sexes.

Although growth-reducing effects of continuous estrogen exposure on developing fish have been shown in some studies, less information is available whether estrogen exposure during specific developmental stages leads to altered growth later in life. Treatment of embryonic trout with estrogen-receptor-binding alkylphenols until 21 DPF resulted in a permanently suppressed growth until 400 DPF (Ashfield et al. 1998). This finding agrees with our observation that developmental estrogen exposure evoked a persistent reduction of tilapia growth. The question is if this permanent growth-suppressing effect is caused by an interaction with the GH/IGF-I system, be it directly and/or indirectly. To this end, we analyzed parameters of the GH/IGF-I system, in a series of target and effector organs, and both at the transcriptional and translational level. Early life treatment of tilapia with $\mathrm{EE}_{2}$ resulted in a significant decrease in circulating serum IGF-I by about $30 \%$ at 75 DPF, i.e., about 1 month after end of treatment. The lowered serum IGF-I was paralled by a high and significant decrease in IGF-I mRNA in liver, the main source of endocrine IGF-I, and a reduced number of IGF-I mRNA expressing hepatocytes as shown by in situ hybridization. Further, the decline in hepatic IGF-I synthesis was accompanied by a significant induction of ER $\alpha$ mRNA, which was most pronounced at the time of the strongest decline of hepatic IGF-I expression. ER $\alpha$ mRNA was induced by $\mathrm{EE}_{2}$ treatment also in other tissues such as pituitary or brain, and this response represents the wellcharacterized autoregulatory effect of estrogens on their own receptors, as it has been shown for other fish species too (Filby et al. 2006). However, it needs to be emphasized that the 


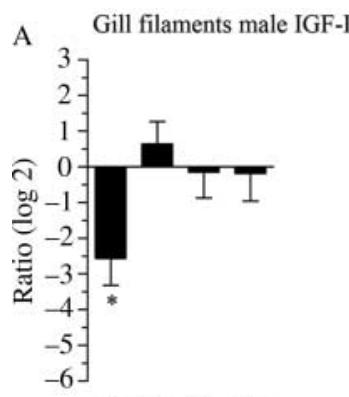

$\begin{array}{llll}50 & 75 & 90 & 165\end{array}$

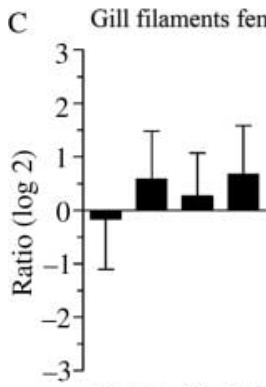

$\begin{array}{llll}50 & 75 & 90 & 165\end{array}$

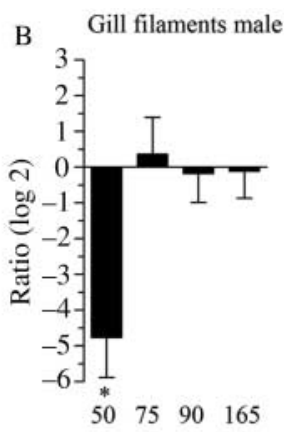

Gill filaments female ER $\alpha$

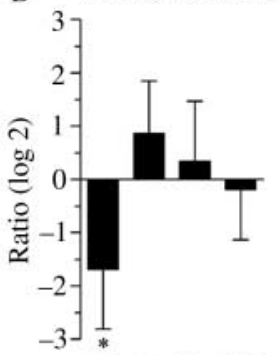

$\begin{array}{llll}50 & 75 & 90 & 165\end{array}$

Gill filaments male IGF-I (50 DPF)

E Control

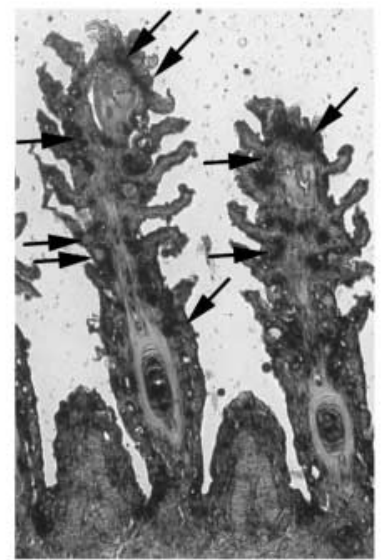

$\mathrm{F} \quad \mathrm{EE}_{2}$-treated

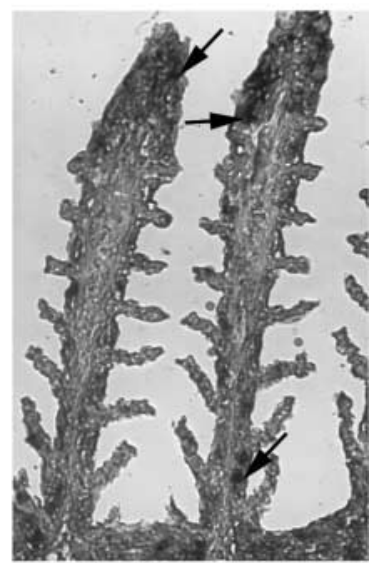

Figure 6 Influence of $E_{2}$ exposure on IGF-I and ER $\alpha$ mRNA in gill filaments. Relative changes $(\log 2)$ of $(A$ and C) IGF-I and (B and D) ER $\alpha$ mRNA expression in $\mathrm{EE}_{2}$-treated tilapia when compared with age-matched control tilapia. Control (male: $50 \mathrm{DPF} n=12,75 \mathrm{DPF} n=9,90$ DPF $n=9,165$ DPF $n=9$; female: $50 \mathrm{DPF} n=15,75 \mathrm{DPF} n=12,90 \mathrm{DPF} n=14,165 \mathrm{DPF} n=12)$ and $\mathrm{EE}_{2}$-treated (male: $50 \mathrm{DPF} n=12$, 75 DPF $n=10,90$ DPF $n=12,165$ DPF $n=11$, female: 50 DPF $n=12,75$ DPF $n=12$, 90 DPF $n=14,165$ DPF $n=11$ ) tilapia were used. Normalization was performed with $\beta$-actin as house-keeping gene. (E and F) In situ hybridization with IGF-I antisense probe in gill specimens of 50 DPF male tilapia. Black arrows point to IGF-I mRNA containing chloride cells in the gill filament epithelium. $X$-axis is labeled as DPF. Columns denote mean values and bars denote s.D. Significance level: ${ }^{*} P=0 \cdot 03, P=0 \cdot 02$.

association between upregulation of $\mathrm{ER} \alpha$ and altered expression of IGF-I, as observed in the present study, does not implicate a mechanistic link between the two observations. However, even without assuming a causative role of the $\mathrm{EE}_{2}$-induced activation and upregulation of the $\mathrm{ER}$ pathway, our results suggest that administration of $\mathrm{EE}_{2}$ during early development exerts a long-term suppressive effect on hepatic IGF-I expression and synthesis. Previous in vivo and in vitro studies in adults of different fish species also reported an estrogen-associated decrease in hepatic IGF-I mRNA (Riley et al. 2004, Carnevali et al. 2005, Filby et al. 2006) or in serum IGF-I (Arsenault et al. 2004, McCormick et al. 2005).

However, those effects occurred during ongoing estrogen treatment while the effects observed in our study represent lasting effects of exposure earlier in life. The $\mathrm{EE}_{2}$ effect on IGF-I of tilapia was partly gender specific. For instance, the $\mathrm{EE}_{2}$-induced decrease in liver IGF-I mRNA appeared earlier (50 DPF) in males than in females (75 DPF). Interestingly, this was paralled by a later increase in ER $\alpha$ mRNA expression in females, suggesting a causative link between these events, although we cannot prove this on the basis of our data. Sexspecific responses of the IGF-I system of fish to estrogens have also been reported by Filby et al. (2006), who found that the hepatic expression of IGF-I in adult fathead minnow exhibited a high and significant decrease in males exposed to $\mathrm{E}_{2}$ but only an insignificant one in females. Gender differences in the response of IGF-I to estrogens may indicate that the estrogen effects on IGF-I expression in organs such as the liver do not only result from a direct, local crosstalk between the two hormone systems, but also interactions at the hypothalamus-pituitary level and subsequent systemic changes may be involved as well. Interestingly, brain IGF-I mRNA was responsive to developmental $\mathrm{EE}_{2}$ treatment only in female tilapia. Here the suppression of IGF-I expression obtained by PCR was paralled by an overall decrease in IGF-I mRNA signals in neurons as found by in situ hybridization.

Furthermore, $\mathrm{EE}_{2}$-treated fish of either sex exhibited a significant decrease in GH mRNA, which was accompanied by a significant upregulation of the ER $\alpha$. Evidence for effects of estrogens on fish pituitary GH gene is conflicting. While in some studies no effects of $\mathrm{E}_{2}$ on GH mRNA were revealed (Melamed et al. 1998, Filby et al. 2006), others report that $\mathrm{E}_{2}$ stimulated GH synthesis and secretion, but not gene transcription (Holloway \& Leatherland 1997, Zou et al. 1997). The discrepancy between these studies and the present one may be due to the different estrogens used, to different modes of application or to hormone application at different life stages or physiological states of the fish. The reduction in pituitary GH mRNA as observed here may well be caused by a direct effect of $\mathrm{EE}_{2}$ on the pituitary $\mathrm{GH}$ cells. However, $\mathrm{EE}_{2}$ 


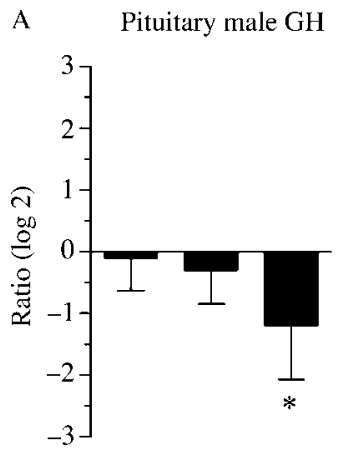

$\begin{array}{lll}75 & 90 & 165\end{array}$

C Pituitary female GH

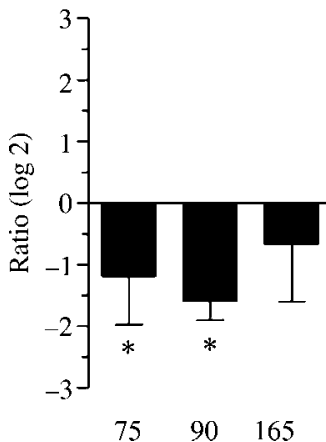

B

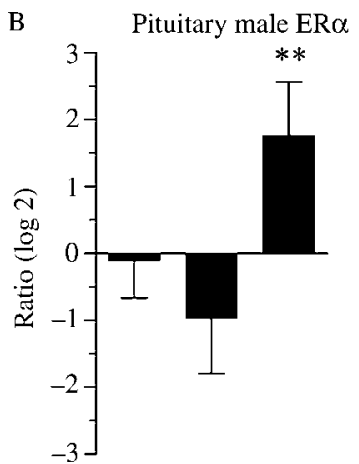

$\begin{array}{lll}75 & 90 & 165\end{array}$

D Pituitary female ER $\alpha$

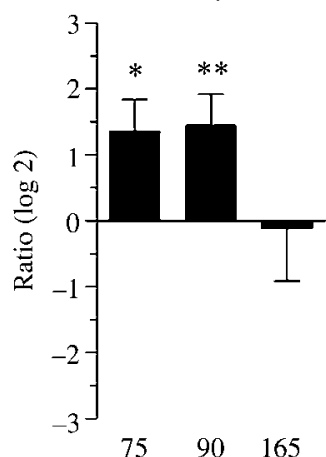

Figure 7 Influence of $\mathrm{EE}_{2}$ exposure on $\mathrm{GH}$ and $\mathrm{ER} \alpha \mathrm{mRNA}$ levels in tilapia pituitary revealed by real-time PCR. Relative changes $(\log 2)$ of ( $A$ and $C$ ) $\mathrm{GH}$ and (B and $\mathrm{D}) \mathrm{ER} \alpha \mathrm{mRNA}$ expression in $\mathrm{EE}_{2}$-treated tilapia when compared with age-matched control tilapia. Control (male: 50 DPF $n=12,75$ DPF $n=9$, 90 DPF $n=9,165$ DPF $n=9$; female: $50 \mathrm{DPF} n=15,75 \mathrm{DPF} n=12,90 \mathrm{DPF} n=14,165 \mathrm{DPF} n=12$ ) and $\mathrm{EE}_{2}$-treated (male: $50 \mathrm{DPF} n=12,75 \mathrm{DPF} n=10,90 \mathrm{DPF} n=12$, 165 DPF $n=11$, female: 50 DPF $n=12,75$ DPF $n=12,90$ DPF $n=14$, 165 DPF $n=11$ ) tilapia were used. Normalization was performed with $\beta$-actin as house-keeping gene. White columns correspond to controls and black columns to $\mathrm{EE}_{2}$-treated fish. $X$-axis is labeled as DPF.

Columns denote mean values and bars denote s.D. Significance level: ${ }^{*} P=0 \cdot 0159, P=0.0571,{ }^{*} P=0 \cdot 0061, P=0.0012$.

may also have suppressed $\mathrm{GH}$ release at the hypothalamic level because $E_{2}$ increased the expression of somatostatin-14 in the goldfish brain (Canosa et al. 2002).

In the gonads, IGF-I occurs during the juvenile and adult stage in testes in spermatogonia, spermatocytes, Sertoli and Leydig cells (Le Gac et al. 1996, Reinecke et al. 1997, Berishvili et al. $2006 b$ ) and in the ovary in small and previtellogenic oocytes and in follicular granulosa and theca cells (Schmid et al. 1999, Perrot et al. 2000, Berishvili et al. 2006b). In Japanese eel cultured testes, IGF-I stimulated spermatogenesis induced by 11-ketosterone (Nader et al. 1999). In rainbow trout, testicular IGF-I increased after GH treatment (Le Gac et al. 1996, Biga et al. 2004) and both GH and IGF-I stimulated the incorporation of thymidine into spermatogonia and primary spermatocytes (Loir 1999). In the ovary of different fish species, IGF-I stimulated thymidine incorporation in vitellogenic follicles (Srivastava \& Van der Kraak 1994), promoted oocyte maturation (Kagawa et al. 1994, Negatu

et al. 1998) and selectively influenced the production of sex steroids in theca and granulosa cells (Maestro et al. 1997). Hence, IGF-I most likely acts as a paracrine/autocrine regulator of fish spermatogenesis and oocyte proliferation and maturation in interaction with steroid hormones.

$\mathrm{EE}_{2}$ treatment caused a significant reduction in IGF-I mRNA in both ovaries and testes. The downregulation occurred earlier in female than in male gonad. In agreement with the PCR results, in situ hybridization in testes showed a decrease in the number of IGF-I mRNA containing spermatogonia, and in ovary a reduction of IGF-I expression in small oocytes and granulosa cells after $\mathrm{EE}_{2}$ treatment. Remarkably, the ER $\alpha$ mRNA showed a long-term induction by $\mathrm{EE}_{2}$ exposure only in the testes, while in the female gonad a significant downregulation of the ER $\alpha$ mRNA was obtained at 75 DPF after an initial upregulation at 50 DPF. Similarly, in adult fathead minnow exposed to $\mathrm{E}_{2}$ for 14 days, ER $\alpha \mathrm{mRNA}$ was also increased in male and decreased in female gonad (Filby et al. 2006). Thus, ER-signaling pathway and IGF-I expression of male and female gonads show differential responses to $\mathrm{EE}_{2}$ exposure what might indicate that in this case the $\mathrm{EE}_{2}$ effects on IGF-I are not mediated through the ER pathway.

Overall, from the present results, two options for explaining the impairing effects of estrogens on growth, differentiation, and function of fish gonads (Jobling et al. 2002, Rasmussen et al. 2002, Fenske et al. 2005) are likely: they may be exerted via suppression of IGF-I production in liver resulting in a lowered level of circulating (endocrine) IGF-I and/or by the reduction of autocrine/paracrine IGF-I expression within the gonads.

In gill filaments, only males exhibited a significant decrease in IGF-I mRNA at 50 DPF that is reflected at the cellular level by a reduction of the number of IGF-I mRNA containing chloride cells, while no significant changes were present throughout the experimental period in females. The results at 50 DPF, i.e., 10 days after end of the treatment, agree in part with those obtained in the adult cyprinid fathead minnow exposed to $\mathrm{E}_{2}$ for 14 days (Filby et al. 2006): IGF-I mRNA was amplified only in the gills of some fish and here a down-regulation was found in both sexes. IGF-I seems to have a physiological impact on smoltification. The chloride cells of the filament epithelium not only express $\mathrm{Na}^{+}, \mathrm{K}^{+}$ ATPase (McCormick 1996) but also in developing and adult fish IGF-I mRNA (Reinecke et al. 1997, Radaelli et al. 2003, Berishvili et al. 2006a). In tilapia, the importance of local IGF-I expression is stressed by its very early appearance in chloride cells around 6-7 DPF (Berishvili et al. 2006a). In several fish species, evidence has been presented that both circulating (liver-derived) IGF-I (Madsen \& Bern 1993, Shepherd et al. 1997, Inoue et al. 2003) and autocrine/ paracrine IGF-I from the chloride cells (Sakamoto \& Hirano 1993, Biga et al. 2004) mediate the osmoregulatory actions of GH. Previous studies have reported that $\mathrm{E}_{2}$ impairs osmoregulation in salmonid (Arsenault et al. 2004, Madsen et al. 2004, McCormick et al. 2005) and non-salmonid (Vijayan et al. 2001) fish, and suppressed plasma levels of 
IGF-I were thought to be the underlying mechanism (McCormick et al. 2005). The present results not only support this idea but also suggest a direct effect of estrogens on IGF-I productionin gill filaments in addition to the endocrine route. This is not only indicated by the present PCR results but also by the observed decrease of IGF-I mRNA in chloride cells as revealed by in situ hybridization.

In summary, the findings from the present study on developing fish are in line with some earlier findings on adult fish that estrogen(s) are able to modulate IGF-I transcription and translation in liver. In addition, the study provides evidence that estrogens applied during early development: a) change the IGF-I system in liver and, concomitantly, circulating IGF-I and, thus, influence the endocrine route of IGF-I action, b) impair local IGF-I in other organs by changing IGF-I expression within the organ-specific cells as shown by in situ hybridization, and c) that the IGF-I response is associated with a change of pituitary GH expression. Thus, the estrogen effect on IGF-I seems to involve both direct (autocrine/paracrine) interactions in peripheral organs as well as indirect (endocrine) effects via modulation of the brainpituitary GH system.

Finally, our results for the first time provide evidence that developmental estrogen exposure can have long-lasting effects on the GH/IGF-I system. As individual growth has consequences for demographic parameters such as age-specific survival, time to maturation or fecundity, our findings point to a potentially important mechanism through which environmental estrogens, in addition to their direct effect on fish reproduction, could alter population growth of fish species.

The present study aimed to reveal whether interactions between the estrogen and the GH/IGF-I system in principal can take place; to this end, we used a dietary $\mathrm{EE}_{2}$ concentration in the range used for intended feminization of tilapia in aquaculture (for literature see Piferrer 2001). Future research would now have to examine the estrogenIGF-I interaction at environmentally relevant exposure concentrations. Importantly, (xeno)estrogens are not bioaccumulative like many of the classical environmental toxicants, such as polychlorinated biphenyls (PCBs). Accordingly, food chain transfer of estrogens has not been demonstrated to date and the dietary exposure route appears to play no significant role. Dietary application of estrogens, similar to injection of estrogens that has also often been described, therefore represents an artificial exposure situation, which is useful to provide principal information on mechanisms and targets but not to assess the environmental hazard of estrogens. Future research has to address the environmental relevance of the effects observed in the present study as well as the mechanism(s) through which estrogen(s) act to suppress pituitary GH and local IGF-I expression in liver and extrahepatic sites. In particular, given our findings on the correlation between ER and IGF-I changes, it would be important to examine whether the $\mathrm{EE}_{2}$ effects on the $\mathrm{GH} /$ IGF-I system are mediated through the ER pathway and/or through other mechanisms.

\section{Acknowledgements}

This work was supported by the Swiss National Research Foundation (NRP 50, project 4050-66580). The authors declare that there is no conflict of interest that would prejudice the impartiality of this scientific work.

\section{References}

Arsenault JT, Fairchild WL, MacLatchy DL, Burridge L, Haya K \& Brown SB 2004 Effects of water-borne 4-nonylphenol and $17 \beta$-estradiol exposures during parr-smolt transformation on growth and plasma IGF-I of Atlantic salmon (Salmo salar L). Aquatic Toxicology 66 255-265.

Ashfield LA, Pottinger TG \& Sumpter JP 1998 Exposure of female juvenile rainbow trout to alkylphenolic compounds results in modification to growth and ovosomatic index. Environmental Toxicology and Chemistry 17 679-686.

Ber R \& Daniel V 1992 Structure and sequence of the growth hormoneencoding gene from Tilapia nilotica. Gene 113 245-250.

Berishvili G, Shved N, Eppler E, Clota F, Baroiller J-F \& Reinecke M $2006 a$ Organ-specific expression of IGF-I during early development of bony fish as revealed in the tilapia, Oreochromis niloticus, by in situ hybridisation and immunohistochemistry: Indication for the particular importance of local IGF-I. Cell Tissue Research 325 287-301.

Berishvili G, D'Cotta H, Baroiller J-F, Segner H \& Reinecke M $2006 b$ Differential expression of IGF-I mRNA and peptide in the male and female gonad during early development of a bony fish, the tilapia Oreochromis niloticus. General and Comparative Endocrinology 146 204-210.

Biga PR, Schelling GT, Hardy RW, Cain KD, Overturf K \& Ott TL 2004 The effects of recombinant bovine somatotropin (rbST) on tissue IGF-I, IGF-I receptor, and GH mRNA levels in rainbow trout, Oncorhynchus mykiss. General and Comparative Endocrinology 135 324-333.

Caelers A, Berishvili G, Meli ML, Eppler E \& Reinecke M 2004 Establishment of a real-time RT-PCR for the determination of absolute amounts of IGF-I and IGF-II gene expression in liver and extrahepatic sites of the tilapia. General and Comparative Endocrinology 137 196-204.

Caelers A, Maclean N, Hwang G, Eppler E \& Reinecke M 2005 Expression of endogenous and exogenous growth hormone $(\mathrm{GH})$ in a GH-transgenic tilapia (Oreochromis niloticus). Transgenic Research 14 95-104.

Canosa LF, Lin X \& Peter RE 2002 Regulation of expression of somatostatin genes by sex steroid hormones in goldfish forebrain. Neuroendocrinology 76 8-17.

Carnevali O, Cardinali M, Maradonna F, Parisi M, Olivotto I, PolzonettiMagni AM, Mosconi G \& Funkenstein B 2005 Hormonal regulation of hepatic IGF-I and IGF-II gene expression in the marine teleost Sparus aurata. Molecular Reproduction and Development 71 12-18.

Chang XT, Kobayashi T, Todo T, Ikeuchi T, Yoshiura Y, Kajiura-Kobayashi H, Morrey C \& Nagahama Y 1999 Molecular cloning of estrogen receptors alpha and beta in the ovary of a teleost fish, the tilapia (Oreochromis niloticus). Zoological Science 16 653-658.

Duan C 1998 Nutritional and developmental regulation of insulin-like growth factors in fish. Journal of Nutrition 128 (2 Suppl) 306S-314S

Duguay SJ, Lai-Zhang J, Steiner DF, Funkenstein B \& Chan SJ 1996 Developmental and tissue-regulated expression of IGF-I and IGF-II mRNAs in Sparus aurata. Journal of Molecular Endocrinology 16 123-132.

Dzidic A, Prgomet C, Mohr A, Meyer K, Bauer J, Meyer HHD \& Pfaffl MW 2006 Effects of mycophenolic acid on inosine monophosphate dehydrogenase I and II mRNA expression in white blood cells and various tissues in sheep. Journal of Veterinary Medicine A 53 163-169.

Eppler E, Caelers A, Shved N, Hwang G, Rahman AM, Maclean N, Zapf J \& Reinecke M 2007 Insulin-like growth factor I (IGF-I) in a growthenhanced transgenic (GH-overexpressing) bony fish, the tilapia (Oreochromis niloticus): indication for a higher impact of autocrine/paracrine than of endocrine IGF-I. Transgenic Research 16 479-489. 
Fenske M, Maack G, Schäfers C \& Segner H 2005 An environmentally relevant concentration of estrogen induces arrest of male gonad development in zebrafish, Danio rerio. Environmental Toxicology and Chemistry 24 1088-1098.

Filby AL, Thorpe KL \& Tyler CR 2006 Multiple molecular effect pathways of an environmental oestrogen in fish. Journal of Molecular Endocrinology 37 121-134.

Le Gac F, Loir M, Le Bail P-Y \& Ollitrault M 1996 Insulin-like growth factor I (IGF-I) mRNA and IGF-I receptor in trout testis and in isolated spermatogenic and Sertoli cells. Molecular Reproduction and Development 44 23-35.

Holloway AC \& Leatherland JF 1997 Effect of gonadal steroid hormones on plasma growth hormone concentrations in sexually immature rainbow trout, Oncorhynchus mykiss. General and Comparative Endocrinology 105 246-254.

Hwang GL, Rahman AM, Razak AS, Sohm F, Farahmand H, Smith A, Brooks C \& Maclean N 2003 Isolation and characterisation of tilapia $\beta$-actin promoter and comparison of its activity with carp $\beta$-actin promoter. Biochimica et Biophysica Acta 1625 11-18.

Inoue K, Iwatani H \& Takei Y 2003 Growth hormone and insulin-like growth factor I of a Euryhaline fish Cottus kazika: cDNA cloning and expression after seawater acclimation. General and Comparative Endocrinology 131 77-84.

Jobling S, Beresford N, Nolan M, Rodgers-Gray T, Brighty GC, Sumpter JP \& Tyler CR 2002 Altered sexual maturation and gamete production in wild roach (Rutilus rutilus) living in rivers that receive treated sewage effluents. Biology of Reproduction 66 272-281.

Jones JI \& Clemmons DR 1995 Insulin-like growth factors and their binding proteins: biological actions. Endocrine Reviews 16 3-34.

Kagawa H, Kobayashi M, Hasegawa Y \& Aida K 1994 Insulin and insulin-like growth factors I and II induce final maturation of oocytes of red seabream, Pagrus major, in vitro. General and Comparative Endocrinology 95 293-300.

Livak KJ \& Schmittgen TD 2001 Analysis of relative gene expression data using real-time quantitative PCR and the $2(-$ Delta Delta $C(\mathrm{t}))$ method. Methods 25 402-408.

Loir M 1999 Spermatogonia of rainbow trout: II. in vitro study of the influence of pituitary hormones, growth factors and steroids on mitotic activity. Molecular Reproduction and Development 53 434-442.

Madsen SS \& Bern HA 1993 In vitro effects of insulin-like growth factorI on gill $\mathrm{Na}^{+}, \mathrm{K}^{+}$-ATPase in coho salmon, Oncorhynchus kisutch. Journal of Endocrinology 138 23-30.

Madsen SS, Skovbolling S, Nielsen C \& Korsgaard B 2004 17- $\beta$ estradiol and 4-nonylphenol delay smolt development and downstream migration in Atlantic salmon, Salmo salar. Aquatic Toxicology 68 109-120.

Maestro MA, Planas JV, Moriyama S, Gutierrez J, Planas J \& Swanson P 1997 Ovarian receptors for insulin and insulin-like growth factor I (IGF-I) and effects of IGF-I on steroid production by isolated follicular layers of the preovulatory coho salmon ovarian follicle. General and Comparative Endocrinology 106 189-201.

McCormick SD 1996 Effects of growth hormone and insulin-like growth factor I on salinity tolerance and gill $\mathrm{Na}^{+}, \mathrm{K}^{+}$-ATPase in Atlantic Salmon (Salmo salar): interaction with cortisol. General and Comparative Endocrinology 101 3-11.

McCormick SD, O’Dea MF, Moeckel AM, Lerner DT \& Bjornsson BT 2005 Endocrine disruption of parr-smolt transformation and seawater tolerance of Atlantic salmon by 4-nonylphenol and 17ß-estradiol. General and Comparative Endocrinology 142 280-288.

Melamed P, Rosenfeld H, Elizur A \& Yaron Z 1998 Endocrine regulation of gonadotropin and growth hormone gene transcription in fish. Comparative Biochemistry and Physiology. Part C, Pharmacology, Toxicology and Endocrinology 119 325-338.

Nader MR, Miura T, Ando N, Miura C \& Yamauchi K 1999 Recombinant human insulin-like growth factor I stimulates all stages of 11-ketotestosterone-induced spermatogenesis in the Japanese eel, Anguilla japonica, in vitro. Biology of Reproduction 61 944-947.

Negatu Z, Hsiao SM \& Wallace RA 1998 Effects of insulin-like growth factor-I on final oocyte maturation and steroid production in Fundulus heteroclitus. Fish Physiology and Biochemistry 19 13-21.

Perrot V, Moiseeva EB, Gozes Y, Chan SJ, Ingleton P \& Funkenstein B 1999 Ontogeny of the insulin-like growth factor system (IGF-I, IGF-II, and IGF-IR) in gilthead seabream (Sparus aurata): expression and cellular localization. General and Comparative Endocrinology 116 445-460.
Perrot V, Moiseeva EB, Gozes Y, Chan SJ \& Funkenstein B 2000 Insulin-like growth factor receptors and their ligands in gonads of a hermaphroditic species, the gilthead seabream (Sparus aurata): expression and cellular localization. Biology of Reproduction 63 229-241.

Piferrer F 2001 Endocrine sex control strategies for the feminisation of fish. Aquaculture 197 229-281.

Plisetskaya EM 1998 Some of my not so favorite things about insulin and insulin-like growth factors in fish. Comparative Biochemistry and Physiology. Part B, Biochemistry and Molecular Biology 121 3-11.

Radaelli G, Domeneghini C, Arrighi S, Bosi G, Patruno M \& Funkenstein B 2003 Localization of IGF-I, IGF-I receptor, and IGFBP-2 in developing Umbrina cirrosa (Pisces: Osteichthyes). General and Comparative Endocrinology $130232-244$

Rasmussen TH, Andreassen TK, Pedersen SN, Van der Ven LTM, Bjerregaard P \& Korsgaard B 2002 Effects of waterborne exposure of octylphenol and estrogen on pregnant viviparous eelpout (Zoarces viviparous) and her embryos in ovario. Journal of Experimental Biology 205 3857-3876.

Reinecke M 2006 Insulin-like growth factor I and II in fish. In Fish Endocrinology, vol 1, pp 87-130. Eds M Reinecke, G Zaccone \& BG Kapoor. Enfield, Jersey, Plymouth: Science Publishers.

Reinecke M \& Collet C 1998 The phylogeny of the insulin-like growth factors. International Review of Cytology 183 1-94.

Reinecke M, Schmid A, Ermatinger R \& Loffing-Cueni D 1997 Insulin-like growth factor I in the teleost Oreochromis mossambicus, the tilapia: gene sequence, tissue expression, and cellular localization. Endocrinology 138 3613-3619.

Riley LG, Hirano T \& Grau EG 2004 Estradiol-17 $\beta$ and dihydrotestosterone differentially regulate vitellogenin and insulin-like growth factor-I production in primary hepatocytes of the tilapia Oreochromis mossambicus. Comparative Biochemistry and Physiology. Toxicology and Pharmacology 138 177-186.

Sakamoto T \& Hirano T 1993 Expression of insulin-like growth factor I gene in osmoregulatory organs during seawater adaptation of the salmonids fish: possible mode of osmoregulatory action of growth hormone. PNAS 90 1912-1916.

Schmid AC, Naef E, Kloas W \& Reinecke M 1999 IGF-I and IGF-II in the ovary of a bony fish Oreochromis mossambicus, the tilapia: in situ hybridisation, immunohistochemical localisation, northern blot and cDNA sequences. Molecular and Cellular Endocrinology 156 141-149.

Shepherd BS, Sakamoto T, Nishioka RS, Richman NH III, Mori I, Madsen SS, Chen TT, Hirano T, Bern HA \& Grau EG 1997 Somatotropic actions of the homologous growth hormone and prolactins in the euryhaline teleost, the tilapia, Oreochromis mossambicus. PNAS 94 2068-2072.

Srivastava RK \& Van der Kraak G 1994 Regulation of DNA-synthesis in goldfish ovarian follicles by hormones and growth factors. Journal of Experimental Zoology 270 263-272.

Vijayan MM, Takemura A \& Mommsen TP 2001 Estradiol impairs hypoosmoregulatory capacity in the euryhaline tilapia, Oreochromis mossambicus. American Journal of Physiology 281 R1161-R1168.

Vong QP, Chan KM \& Cheng CH 2003 Quantification of common carp (Cyprinus carpio) IGF-I, IGF-II mRNA by real-time PCR: differential regulation of expression by GH. Journal of Endocrinology 178 513-521.

Wood AW, Duan C \& Bern HA 2005 Insulin-like growth factor signaling in fish. International Review of Cytology 243 215-285.

Zapf J, Gosteli-Peter M, Weckbecker G, Hunziker EB \& Reinecke M 2002 The somatostatin analog octreotide inhibits GH-stimulated, but not IGF-Istimulated, bone growth in hypophysectomized rats. Endocrinology 143 2944-2952.

Zou JJ, Trudeau VL, Cui Z, Brechin J, Mackenzie K, Zhu Z, Houlihan DF \& Peter R 1997 Estradiol stimulates growth hormone production in female goldfish. General and Comparative Endocrinology 106 102-112.

\section{Received in final form 5 September 2007 Accepted 12 September 2007 Made available online as an Accepted Preprint 12 September 2007}

